\title{
The Quality of Ecologically and Conventionally Grown White and Brown Agaricus bisporus Mushrooms
}

\author{
Aurelija Paulauskiené ${ }^{1}\left(\mathbb{D}\right.$, Živilè Tarasevičienè ${ }^{1}$, Daiva Šileikiené ${ }^{2}$ and Laima Česoniene ${ }^{2, *}$ (D) \\ 1 Institute of Agricultural and Food Sciences, Faculty of Agronomy, Vytautas Magnus University Agriculture \\ Academy, Studentu str. 11, LT-53361 Akademija, Kauno r., Lithuania; aurelija.paulauskiene@vdu.lt (A.P.); \\ zivile.taraseviciene@vdu.lt (Ž.T.) \\ 2 Institute of Environment and Ecology, Faculty of Forest Science and Ecology, Vytautas Magnus University \\ Agriculture Academy, Studentu str. 11, LT-53361 Akademija, Kauno r., Lithuania; daiva.sileikiene@vdu.lt \\ * Correspondence: laima.cesoniene1@vdu.lt
}

Received: 2 July 2020; Accepted: 30 July 2020; Published: 31 July 2020

check for updates

\begin{abstract}
Agaricus bisporus is a rich source of biologically active compounds with functional properties that have a positive effect on human health. White and brown A. bisporus mushrooms were grown both organically and conventionally. This study aimed to analyze chemical composition of the mushrooms, their electrochemical properties, and the composition of volatile compounds. The relationships between cultivation practices and the basic chemical composition, electrochemical properties, and aroma compounds of A. bisporus were examined. The results reveal that ecologically grown mushrooms accumulated higher amounts of ascorbic acid while conventionally grown mushrooms accumulated more crude protein and zinc. More substantial amounts of dry matter, crude protein, and crude ash were found in the brown mushrooms. The white mushrooms had a higher content of ascorbic acid, crude fat, and dietary fiber. Ten volatile compounds were tentatively identified in analyzed mushrooms, including five aldehydes, two esters, two alcohols, and one terpene. Conventionally grown mushrooms had a higher $\mathrm{pH}$ value, but eco mushrooms had significantly lower redox potential. White mushrooms had lower $p$-values than brown mushrooms. Eco mushrooms could not be distinguished by their qualitative characteristics. The chemical composition of white and brown mushrooms was somewhat different, and only the electrochemical properties of mushrooms differed significantly.
\end{abstract}

Keywords: Agaricus bisporus; chemical composition; electrochemical properties; volatile compounds

\section{Introduction}

In the EU, organic farming is a successful way to address multiple challenges. The organic agriculture movement highlights the role that organic food and farming can play in achieving more sustainable food systems, pointing to the fact that the organic market is growing quickly, proving that European citizens demand high-quality food that also delivers a range of societal benefits [1]. Consumer demand for organic production grows by double-digits every year [2], and as the range of organic products is expanding, sales of ecologically grown mushrooms are on the rise.

Nowadays, interest in mushrooms has increased all over the world due to their nutritional and medical properties [3]. Agaricus bisporus is an edible mushroom native to grasslands in Europe and North America and is cultivated commercially in large quantities on composted substrate. A. bisporus mushrooms are considered to be nutraceuticals and functional foods because they contain large amounts of bioactive compounds, such as polyphenols, polysaccharides, vitamins, carotenoids, and minerals, and have both beneficial and nutritional effects on one or more functions of the body, improving health, 
well-being, and lowering the risk of illness [4-7]. The high nutritional value of edible mushrooms depends on high protein, high fiber, and low-fat levels [3]. Mushrooms produce a large number of proteins and peptides (such as lectins, fungal immunomodulatory proteins, ribosome-inactivating proteins, antimicrobial proteins, ribonucleases, and laccases) with important biological activities [8]. Some investigators have even contended that the amino acid composition of mushrooms is comparable to animal proteins [9]. They are very useful for vegetarian diets because they provide all the essential amino acids for adult requirements; in addition, mushrooms have a higher protein content than most vegetables, improving the dietary diversity without adding many calories $[3,6]$. Mushrooms are a rich source of some novel dietary fiber. Mushroom cell walls contain a mixture of fibrillar and matrix components, which include chitin and polysaccharides, such as $\beta$-D-glucans and mannans, respectively [10]. Results of tests on rats suggest that the inclusion of $A$. bisporus mushrooms in the daily diet may have beneficial effects on age-related deficits in cognitive and motor function [11]. A. bisporus white button mushrooms constitute the bulk of all mushrooms consumed and contain bioactive compounds that exhibit immunomodulating and anticancer properties [12,13]. The A. bisporus white mushroom is rich in acidic polysaccharides and antioxidants, including vitamin C, riboflavin, niacin, folate, vitamins $B_{12}$ and $D$, polyphenol, and flavonoids $[5,9,14]$. It is known that mushrooms accumulate substrate-related minerals that are either extremely important for the human body (sodium, potassium, calcium, magnesium, and phosphorus) or used for their own antioxidant protection (copper, zinc, manganese, and selenium) [15]. The bioactive compound content depends upon species, nutritive substrate type, pedoclimatic conditions, age of mycelium, processing, and preservation conditions. All these factors lead to wide variability in the biological potential [15].

Mushrooms are also appreciated by cooks and chefs for their texture, flavor, and versatility. Flavor is one of the most important quality attributes contributing to the widespread consumption of cultivated mushrooms. A. bisporus mushrooms are considered a valuable food, not just because of their abundance of bioactive components, but also their delicious taste [16]. The typical flavor of mushrooms consists of non-volatile components, such as free amino acids, 50 nucleotides, organic acids, soluble sugars, and polyols [16], and volatile compounds [17]. Agaricus mushrooms possess a highly intense umami taste, and this might explain why they have long been used as a food or food-flavoring material [16]. More than 80 different volatile compounds of commercial mushrooms have been identified by electronic nose and gas chromatography-mass spectrometry and classified into several categories such as alcohols, aldehydes, ketones, alkenes, terpenes, acids, esters, sulfur, aromatic compounds, and others [17].

The growing interest in organic production requires methods that can simply identify differences in food quality between organically and conventionally grown products [18]. Electrochemical investigations provide additional information about metabolism and physiological processes. Scientists suggest using the measurement of plant redox potential and $\mathrm{pH}$ to rapidly assess the impact of cropping practices on plant health and relate it to soil health $[19,20]$. Life processes in plants can be described as chains of electrochemical or redox reactions [21]. Three factors: $\mathrm{pH}$, redox potential ( $\mathrm{rH}$ in $\mathrm{mV})$, and resistivity ( $R$ in $\Omega$ ), make up the basis of electrochemical tests, which translate into P-value electrochemical parameters of product quality [22]. $P$-value is being tested as an integrative holistic method of product quality assessment. According to the Bioelectric Vincent method, better product quality or recovered products are attained by low redox potential and P-value, but higher resistivity [23]. These investigations are carried out on live organisms without the destruction of cells and reflect the processes taking place in nature. Application of electrochemical research methods provides the possibility of evaluating vitality of systems and of increasing knowledge about plant suitability for food [22]. Research suggests a new quality concept in which vitality, structure, and coherence are inextricably linked to the life processes of the plant and assumes that processes during the development of the crop are reflected in the properties of the final product [23].

The aim of the research was to compare the chemical composition of $A$. bisporus white and brown mushrooms grown ecologically and conventionally, using chemical and electrochemical methods. 


\section{Materials and Methods}

\subsection{Proximate Composition Analysis}

Ecologically and conventionally grown young A. bisporus mushroom specimens with a closed 30-40-cm diameter cap (3 developmental stage [24]), white and light brown, uniform, clean, and fresh in sealed $250 \mathrm{~g}$ packs were purchased from a Lithuanian producer. Ecologically grown mushrooms were certified with the ecolabels EU organic products label and LT-EKO-001. These mushrooms were grown in a modern farm on the producer own organic mushroom substrate made exclusively from natural ingredients. Conventional mushrooms were grown on the non-organic substrate. All mushrooms were carefully selected and picked by hand. Before analysis, 6 samples of each species (4 species of $1.5 \mathrm{~kg}$ each) were stored in packs in a refrigerator at a temperature of $5^{\circ} \mathrm{C}$. Chemical composition of the mushrooms was analyzed by standard methods. Dry matter (DM) content was assessed by drying the samples to constant mass at $105^{\circ} \mathrm{C}$; and ascorbic acid (AA) was determined by titration with 2.6-dichlorphenol-indophenol sodium salt dihydrate. The amount of crude protein (CP) was estimated by the Kjeldahl method [25]. The crude fat (CF) was determined by extracting a sample with diethyl ether in a Soxhlet apparatus SOXTHERM ${ }^{\circledR}$ (C. Gerhardt GMBH \& CO. KG, Königswinter, Germany) [26]. The amount of crude ash (CA) was determined by dry burning samples at a temperature of $500{ }^{\circ} \mathrm{C}$. The quantity of macroelements was determined from the dry mass (DM) of the mushrooms. The ash samples obtained from the dry-ashing procedure at $500{ }^{\circ} \mathrm{C}$ were dissolved in nitric acid $\left(\mathrm{HNO}_{3}\right)$ and analyzed using inductively coupled plasma mass spectrometry (ICP-MS). The amount of dietary fiber (DF) was determined using a modified version of the Henneberg-Stohmann method [27].

Chemicals used in this study were of analytical grade. Chemical analyses were performed in three replications.

\subsection{Electronic Nose Analysis of Volatile Compounds}

The Heracles II e-nose (AlphaMOS, Toulouse, France), based on ultrafast gas chromatography, was used to analyze the volatile compounds in organically and conventionally grown A. bisporus white and brown mushrooms. The equipment consists of automatic sampling and detector systems. E-nose is equipped with two columns working in parallel mode: a non-polar column MXT-5 and a slightly polar column MXT-1701, $10 \mathrm{~m}$ length and $180 \mu \mathrm{m}$ diameter each, connected with two flame ionization detectors (FID). The researchers placed $2 \mathrm{~g}$ of each lyophilized mushroom sample in a $20 \mathrm{~mL}$ headspace vial and sealed it with a Teflon-faced silicone rubber cap. The vials were placed in the Heracles' auto-sampler, and each vial was incubated at $55^{\circ} \mathrm{C}$ for $6 \mathrm{~min}$ and shaken at $500 \mathrm{rpm}$. Then, a syringe was used to pierce the silicone rubber cap, sample $3.5 \mathrm{~mL}$ of the headspace, and inject it into a gas chromatograph where the injector temperature was $200{ }^{\circ} \mathrm{C}$. The carrier gas $\left(\mathrm{H}_{2}\right)$ flowed at

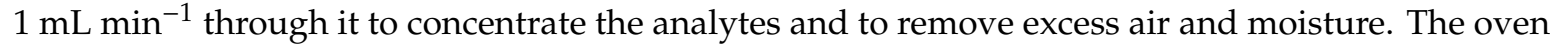
temperature was $55^{\circ} \mathrm{C}$, and the two flame ionization detectors were at $270{ }^{\circ} \mathrm{C}$ [28]. The injection of each sample was carried out on 5 replicates. For calibration, an alkane solution (from n-hexane to n-hexadecane) was used to convert retention time into Kovats retention indices and to identify the volatile compounds using AroChemBase (AlphaMOS).

\subsection{Analysis of Electrochemical Parameters}

Electrochemical parameters were measured in homogenized fresh mushroom samples. The $\mathrm{pH}$ and redox potential $(\mathrm{rH})$ were measured by a $781 \mathrm{pH} / \mathrm{Ion}$ Meter (Metrohm AG, Herisau, Switzerland), and electrical conductivity (electrical conductivity is the reciprocal of electrical resistivity) by a laboratory conductivity meter inoLab ${ }^{\circledR}$ Cond 7310 (Xylem Inc., WTW, Weilheim, Germany). $P$-value as a combined parameter of the three mentioned parameters was calculated according to the formula:

$$
\mathrm{P}=[29.07(\mathrm{rH}-2 \mathrm{pH})]^{2} \cdot \mathrm{rHo}^{-1}(\mu \mathrm{W})
$$


where; $\mathrm{rH}$ is the redox potential $(\mathrm{mV}) ; \mathrm{pH}$ is the hydrogen-ion activity; and $\mathrm{rHo}$ is the recalculated specific electrical conductivity $\left(\mu \mathrm{S} \mathrm{cm}^{-1}\right)$ [29].

\subsection{Statistical Analysis}

Data analysis was carried out with STATISTICA version 7 software (TIBCO Software, Palo Alto, CA, USA). The results were analyzed using one-way analysis of variance (ANOVA). The differences between all the kinds of mushrooms under test were analyzed. Arithmetical means and standard deviations of the experimental data were calculated. Fisher's Least-Significant-Difference test (LSD) was applied to the experimental results to assess significant differences between mean values at the significance level of $p<0.05$.

\section{Results and Discussion}

\subsection{Chemical Composition of A. bisporus White and Brown Mushrooms}

The content of biologically active compounds in mushrooms may vary greatly. Biologically active compounds are affected by differences in strain, substrate, cultivation, and fruiting conditions, the developmental stage of the mushroom, and the age of the fresh mushroom sample [9,30,31]. Some researchers maintain that the DM content of A. bisporus is $7.84 \%$ (with a standard error of 0.70 ), with small or no differences between flushes and crops, while others state it can vary in the range of 9.37-9.62\% [32,33].

In our case, the DM content of $A$. bisporus mushrooms varied from $7.34 \%$ in the white to $8.85 \%$ in the brown (Figure 1). The DM content of white eco mushrooms was significantly more than that in conventionally grown white mushrooms. No significant differences between the two types of brown mushrooms were found. According to researchers, high DM content is always associated with first flush mushrooms and with low watering level and frequency [30]. Under identical growing conditions, DM content varies from one strain to the other; large white and small brown mushrooms have a more substantial DM content than others.

$\square \mathrm{DM}$ 成 $\mathrm{CF} \square \mathrm{CP} \square \mathrm{DF}$ 圈CA $\square \mathrm{AA}$

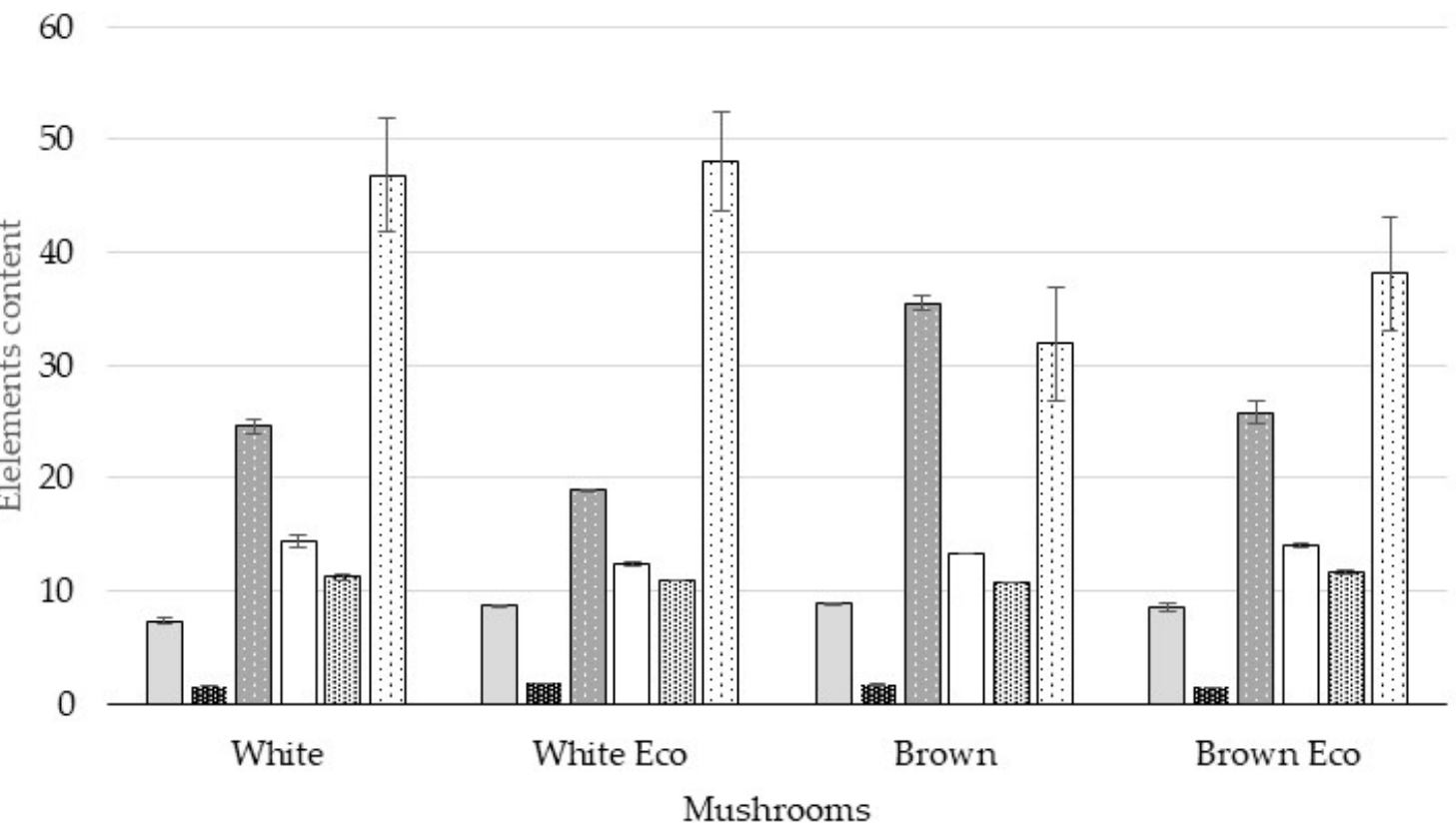

Figure 1. Chemical composition of the analyzed mushrooms Agaricus bisporus. DM, dry matter (\% FW); $\mathrm{CF}$, crude fats (\% DM); $\mathrm{CP}$, crude proteins (\% DM); DF, dietary fibers (\% DM); CA, crude ashes (\% DM); $\mathrm{AA}$, ascorbic acid ( $\left.\mathrm{mg} \mathrm{kg}^{-1} \mathrm{FW}\right)$. 
Cultivated mushrooms contain small amounts of AA. According to published articles, there is a high variation in AA content in A. bisporus mushrooms, which have been reported to contain 2.1-5.5 mg $100 \mathrm{~g}^{-1}$ FW (fresh weight) [4].

The amount of AA in the mushrooms analyzed in this study was similar, $31.92-48.06 \mathrm{mg} \mathrm{kg}^{-1} \mathrm{FW}$ (Figure 1). The most significant amount was in the white eco mushrooms. The white mushrooms of both types accumulated 1.3-1.5-fold more AA content than the brown mushrooms. Different genetic properties may lead to an increase in the AA content in mushrooms.

Mushrooms are low-calorie foods since they provide relatively low amounts of fat [3]. According to previous studies, CF content varied 2.53-3.92\% [16] and 1.90-3.06\% DM [31].

The CF content in the analyzed mushrooms was between $1.43 \%$ and $1.81 \%$ DM (Figure 1 ). White eco mushrooms contained the largest amount of CF.

According to the literature, the $\mathrm{CP}$ content of mushrooms may be between $21.3 \%$ and $27.0 \%$ [16] or between $18 \%$ and $38 \%$ DM [34].

Our data confirm these results. The $\mathrm{CP}$ content fluctuated from $18.85 \%$ in the white eco mushrooms to $35.52 \%$ DM in the brown mushrooms (Figure 1). The brown mushrooms accumulated about 1.4-fold more $\mathrm{CP}$ content. In the eco mushrooms, $\mathrm{CP}$ content was lower in comparison with conventionally grown mushrooms.

The researchers established that the DF content in A. bisporus was 17.7-23.3\% DM [16]. In our study, we found that the amount of DF varied from $12.40 \%$ to $14.37 \%$ DM (Figure 1). DF content did not differ significantly between the white and brown eco mushrooms. However, the lowest amount was found in the white eco mushrooms.

Some researchers stated that white and brown mushrooms produced similar amounts of CA [7]. They found the CA content varied from $7.77 \%$ to $11.39 \%$ DM $[7,16,31]$.

Our data show CA content in white and brown mushrooms ranged from $10.77 \%$ to $11.64 \%$ DM (Figure 1). The CA content was highest in the brown eco mushrooms.

The mineral content of commercially cultivated A. bisporus is undoubtedly affected by the composition of the growth substrate. This is why values for the mineral composition of $A$. bisporus obtained by various investigators are often different $[8,29,35]$. The main constituents in the ash are potassium, phosphorus, and magnesium [9], in addition to calcium, copper, iron, and zinc [35].

Our data show a higher average content of mineral elements in the brown mushrooms (Table 1). The major component of the mushrooms in this study was potassium, and its concentration varied from $41.03 \mathrm{~g} \mathrm{~kg}^{-1}$ in the brown eco to $44.08 \mathrm{~g} \mathrm{~kg}^{-1} \mathrm{DM}$ in the white eco. White mushrooms contained larger amounts of potassium. Our results resemble those of other researchers, who also found greater amounts of potassium in white mushrooms [9].

Table 1. The mineral contents in analyzed mushrooms Agaricus bisporus (in kg of DM).

\begin{tabular}{ccccc}
\hline & White & White Eco & Brown & Brown Eco \\
\hline $\mathrm{K}(\mathrm{g})$ & $43.04 \pm 0.10^{\mathrm{ab}, *}$ & $44.08 \pm 0.10^{\mathrm{a}}$ & $42.10 \pm 0.20^{\mathrm{ab}}$ & $41.03 \pm 0.10^{\mathrm{b}}$ \\
$\mathrm{P}(\mathrm{g})$ & $10.81 \pm 0.01^{\mathrm{c}}$ & $11.80 \pm 0.20^{\mathrm{a}}$ & $11.74 \pm 0.02^{\mathrm{a}}$ & $11.10 \pm 0.01^{\mathrm{b}}$ \\
$\mathrm{Mg}(\mathrm{g})$ & $1.01 \pm 0.05^{\mathrm{a}}$ & $1.02 \pm 0.05^{\mathrm{a}}$ & $1.10 \pm 0.01^{\mathrm{a}}$ & $1.05 \pm 0.06^{\mathrm{a}}$ \\
$\mathrm{Zn}(\mathrm{mg})$ & $69.00 \pm 0.10^{\mathrm{b}}$ & $61.05 \pm 0.10^{\mathrm{c}}$ & $90.80 \pm 0.1^{\mathrm{a}}$ & $68.83 \pm 0.10^{\mathrm{b}}$ \\
\hline
\end{tabular}

${ }^{*}$ Results are expressed as means plus/minus standard deviation. Means in the raw followed by different letters $(\mathrm{ab}, \mathrm{a}, \mathrm{b}, \mathrm{c})$ are significant different $(\mathrm{P}<0.05)$.

The analyzed mushrooms contained a considerable concentration of phosphorus, which was highest in white eco mushrooms, and lowest in conventionally grown white mushrooms. The average contents of phosphorus in the different mushrooms ranged from 10.81 to $11.80 \mathrm{~g} \mathrm{~kg}^{-1} \mathrm{DM}$. These findings are generally in accordance with the original findings by other researchers [33], although some investigators found a slightly higher content of phosphorus in conventionally grown white and brown A. bisporus in the range of $12.7-12.9 \mathrm{~g} \mathrm{~kg}^{-1} \mathrm{DM}[9]$. 
Magnesium represented the third major mineral element (after potassium and phosphorus) found in fungal fruiting bodies [9].

The magnesium content in all analyzed mushrooms did not differ significantly and ranged from 1.01 to $1.10 \mathrm{~g} \mathrm{~kg}^{-1} \mathrm{DM}$. These findings were in accordance with those of other scientists $[9,33]$.

The mushrooms in the study were quite a good source of zinc, the content of which ranged from 61.05 to $90.80 \mathrm{mg} \mathrm{kg}^{-1} \mathrm{DM}$. The zinc levels match those found by other researchers $[9,33]$. The significant highest amount of zinc was found in conventionally grown brown mushrooms. Conventionally grown mushrooms contained larger amounts of zinc in comparison with conventionally grown mushrooms.

\subsection{Volatile Compounds of A. bisporus White and Brown Mushrooms}

Odorous compounds in mushrooms vary with the species and growing conditions. However, each species has a unique odor, and this characteristic can be used to distinguish between different mushroom species [17].

Ten volatile compounds in all the analyzed mushrooms were tentatively identified (Table 2). These included five aldehydes, two esters, two alcohols, and one terpene. Seven volatile compounds were found in white and brown eco mushrooms and six in conventionally grown mushrooms. Only three compounds, i.e., pentanal and both alcohols (benzyl alcohol and 1-nonanol) were detected in all four kinds of mushrooms. One compound, n-nonanal, was characteristic of eco mushrooms regardless of color. Ethyl octanoate was characteristic of brown A. bisporus and p-anisaldehyde of white (Table 2).

Table 2. Characterization of the main tentative volatile compounds identified in the mushrooms Agaricus bisporus by Kovats retention indices.

\begin{tabular}{|c|c|c|c|c|c|c|c|}
\hline $\begin{array}{l}\text { Possible Matches } \\
\text { Compounds }\end{array}$ & Odor Description ${ }^{\text {a }}$ & KI MXT-5 ${ }^{b}$ & $\underset{\text { MXT-17 }^{\mathrm{c}}}{\text { KI }}$ & White & $\begin{array}{l}\text { White } \\
\text { Eco }\end{array}$ & Brown & $\begin{array}{l}\text { Brown } \\
\text { Eco }\end{array}$ \\
\hline \multicolumn{8}{|l|}{ Aldehydes } \\
\hline Pentanal & $\begin{array}{l}\text { Almond; green; herbaceous; } \\
\text { malty; pungent; rubber }\end{array}$ & 691 & 776 & + & + & + & + \\
\hline Furfural & Almond; bread; sweet & 827 & 972 & + & + & & + \\
\hline N-nonanal & $\begin{array}{l}\text { Chlorine; citrus; fatty; floral; } \\
\text { fruity; gaseous; gravy; green; } \\
\text { lavender; melon; soapy; sweet }\end{array}$ & 1100 & 1194 & & + & & + \\
\hline $\begin{array}{l}\text { Benzeneac } \\
\text { etaldehyde }\end{array}$ & $\begin{array}{l}\text { Floral; grassy; green; hawthorn; } \\
\text { honey; rose; sweet }\end{array}$ & 1043 & 1188 & & & + & \\
\hline p-Anisaldehyde & Anise; minty; sweet & 1250 & 1452 & + & + & & \\
\hline \multicolumn{8}{|l|}{ Esters } \\
\hline $\begin{array}{l}\text { Ethyl 2-methyl } \\
\text { Butyrate }\end{array}$ & $\begin{array}{l}\text { Apple; blackberry; fruity; green; } \\
\text { strawberry, sweet }\end{array}$ & 849 & 907 & + & & + & + \\
\hline Ethyl octanoate & $\begin{array}{l}\text { Anise; baked fruity; fatty; floral; } \\
\text { fresh; green; leafy; mentholic; } \\
\text { soapy; sweet; waxy }\end{array}$ & 1196 & 1260 & & & + & + \\
\hline \multicolumn{8}{|l|}{ Terpen } \\
\hline $\begin{array}{l}\text { Alpha-Phel } \\
\text { landrene }\end{array}$ & Minty; spicy; terpenic; turpentine & 1004 & 1029 & & + & & \\
\hline \multicolumn{8}{|l|}{ Alcohols } \\
\hline Benzyl alcohol & Aromatic; floral; fruity; sweet & 1034 & 1220 & + & + & + & + \\
\hline 1-Nonanol & Fatty; floral; fruity; green & 1165 & 1277 & + & + & + & + \\
\hline
\end{tabular}

\subsection{Electrochemical Parameters of A. bisporus White and Brown Mushrooms}

Researchers state that mean valued of $\mathrm{pH}$ and redox potential at plant and organ level can be good indicators, integrating the various stresses as well as beneficial factors by the whole plant, and 
can bring important information and knowledge on molecular redox processes at the cell [19]. The A. bisporus mushrooms investigated in this study showed a $\mathrm{pH}$ range from 6.64 to 6.81 (Table 3).

Table 3. The mineral contents in analyzed mushrooms Agaricus bisporus (in kg of DM).

\begin{tabular}{ccccc}
\hline & White & White Eco & Brown & Brown Eco \\
\hline $\mathrm{pH}$ & $6.81 \pm 0.03^{\mathrm{a}, *}$ & $6.70 \pm 0.40^{\mathrm{b}}$ & $6.70 \pm 0.03^{\mathrm{b}}$ & $6.64 \pm 0.02^{\mathrm{b}}$ \\
Redox potential $(\mathrm{mV})$ & $119.33 \pm 5.50^{\mathrm{b}}$ & $107.33 \pm 3.51^{\mathrm{c}}$ & $170.00 \pm 1.00^{\mathrm{a}}$ & $76.67 \pm 1.15^{\mathrm{d}}$ \\
Electrical conductivity $\left(\mu \mathrm{S} \mathrm{cm}^{-1}\right)$ & $1061.33 \pm 1.53^{\mathrm{b}}$ & $1020.67 \pm 2.77^{\mathrm{c}}$ & $1149.33 \pm 2.52^{\mathrm{a}}$ & $1154.33 \pm 1.53^{\mathrm{a}}$ \\
P value $(\mu \mathrm{W})$ & $3.18 \pm 0.10^{\mathrm{c}}$ & $2.91 \pm 0.03^{\mathrm{d}}$ & $3.57 \pm 0.18^{\mathrm{b}}$ & $5.19 \pm 0.04^{\mathrm{a}}$ \\
\hline
\end{tabular}

* Results are expressed as means plus/minus standard deviation. Means in the raw followed by different letters $(\mathrm{ab}, \mathrm{a}, \mathrm{b}, \mathrm{c})$ are significant different $(\mathrm{P}<0.05)$.

White and brown conventionally grown mushrooms had a higher $\mathrm{pH}$ value compared with eco mushrooms. Several studies with fruit and vegetables have shown that higher $\mathrm{pH}$ means lesser vitality of products [36-38].

The redox potential is of key interest in electrochemical research because it reflects the gradient of electrons that life processes utilize for their cellular work [21]. Investigator states that, when $\mathrm{rH}<28.3$, the systems are reducing and can release electrons to other systems with lower $\mathrm{rH}$; at $\mathrm{rH}>28.3$, the systems are oxidant and can accept electrons from systems with higher $\mathrm{rH}$ [39].

The values of redox potential for our tested mushroom samples were much higher than 28 $\mathrm{mV}$, thus an oxidative environment dominated (Table 3). The data show that white and brown eco mushrooms have significantly less redox potential, as do other organic products, such as carrots [21] and tomato [34]. This means that eco mushroom cells can use free enthalpy for their activities, and the products are more suitable for human consumption [36].

Electrical conductivity of food material is a function of product characteristics (composition, sugar and salt content, and $\mathrm{pH}$ ) and a property that measures a material's ability to conduct an electric current. The electrical conductivity of foods has been found to increase with temperature, water, ionic content, moisture mobility, and physical structure [40].

The electrical conductivity of the tested white and brown mushrooms differed significantly, and the values for brown mushrooms were found to be higher.

$P$-value is used to define the vitality of the organism and energy distribution tendencies [23]. The P-values for tested A. bisporus mushrooms were significantly lower than those for plums [38], carrots [21], pumpkins [36], and tomato [37] (Table 3). White eco mushrooms had the lowest P-values, and commercially cultivated white mushrooms had the next lowest.

\section{Conclusions}

Ecologically grown mushrooms were not distinguishable from conventionally grown mushrooms by their qualitative characteristics. However, quantitative results reveal growing practice influenced the accumulation of ascorbic acid, crude protein, and zinc.

The chemical composition of white and brown mushrooms was different. Greater amounts of dry matter, crude protein, and crude ash were found in the brown mushrooms. The white mushrooms had a higher content of ascorbic acid, crude fat, and dietary fiber. White mushrooms accrued a greater amount of potassium, and white eco mushrooms accumulated the highest phosphorus content. The highest levels of magnesium and zinc were found in the brown mushrooms.

Tentative volatile compounds identified in mushrooms depended on growing practice. Organic production influenced more volatile compounds than conventional and only accumulation of pentanal and both alcohols (benzyl alcohol and 1-nonanol) was not influenced by growing method.

The electrochemical properties of white and brown mushrooms differed significantly. Conventionally grown mushrooms had a higher $\mathrm{pH}$ value compared with eco mushrooms, but eco mushrooms had significantly less redox potential. The lowest $P$-values were obtained for white 
eco mushrooms, and white conventional mushrooms had the next lowest value. Studies of the electrochemical parameters are presented only as complementary and as requiring further and more detailed studies.

Author Contributions: Conceptualization, A.P. and D.Š.; methodology, D.Š.; formal analysis, L.Č.; investigation, A.P.; data curation, Ž.T.; writing—original draft preparation, A.P.; and writing—review and editing, A.P., Ž.T., D.Š., and L.Č. All authors have read and agreed to the published version of the manuscript.

Funding: This research received no external funding.

Conflicts of Interest: The authors declare no conflict of interest.

\section{References}

1. Willer, H.; Lernoud, J.; Kemper, L. The world of organic agriculture 2018: Summary. In The World of Organic Agriculture. Statistics \& Emerging Trends 2018; Willer, H., Lernoud, J., Eds.; Research Institute of Organic Agriculture (FiBL): Frick, Switzerland, 2018; pp. 22-32. Available online: https://orgprints.org/34669/1/ WILLER-LERNOUD-2018-final-PDF-low.pdf (accessed on 12 November 2019).

2. Willer, H.; Meredith, S.; Moeskops, B.; Busacca, E. Organic in Europe: Prospects and developments. In The World of Organic Agriculture. Statistics \& Emerging Trends 2018; Willer, H., Lernoud, J., Eds.; Research Institute of Organic Agriculture (FiBL): Frick, Switzerland, 2018; pp. 210-218. Available online: https: //orgprints.org/34669/1/WILLER-LERNOUD-2018-final-PDF-low.pdf (accessed on 12 November 2019).

3. Atila, F.; Owaid, M.N.; Shariati, A.M. The nutritional and medical benefits of Agaricus Bisporus: A review. J. Microbiol. Biotechnol. Food Sci. 2017, 7, 281-286. [CrossRef]

4. Jaworska, G.; Pogon, K.; Bernas, E.; Duda-Chodak, A. Nutraceuticals and antioxidant activity of prepared for consumption commercial mushrooms Agaricus bisporus and Pleurotus ostreatus. J. Food Qual. 2015, 38, 111-122. [CrossRef]

5. Mircea, C.; Cioanca, O.; Iancu, C.; Tataringa, G.; Hancianu, M. In vitro antioxidant activity of some extracts obtained from Agaricus Bisporus brown, Pleurotus Ostreatus and Fomes Fomentarius. Farmacia 2015, 63, 927-933. Available online: http://www.revistafarmacia.ro/201506/art-23-Mircea_927-933.pdf (accessed on 10 December 2019).

6. Valverde, M.E.; Hernandez-Perez, T.; Paredes-Lopez, O. Edible mushrooms: Improving human health and promoting quality life. Int. J. Microbiol. 2015, 1-14. [CrossRef]

7. Reis, F.S.; Barros, L.; Martins, A.; Ferreira, I.C.F.R. Chemical composition and nutritional value of the most widely appreciated cultivated mushrooms: An inter-species comparative study. Food Chem. Toxicol. 2012, 50, 191-197. [CrossRef] [PubMed]

8. Xu, X.; Yan, H.; Chen, J.; Zhang, X. Bioactive proteins from mushrooms. Biotechnol. Adv. 2011, 29, 667-674. [CrossRef]

9. Mattila, P.; Könkö, K.; Eurola, M.; Pihalava, J.M.; Astola, J.; Vahteristo, L.; Hietaniemi, V.; Kumpulainen, J.; Valtonen, M.; Piironen, V. Contents of vitamins, mineral elements, and some phenolic compounds in cultivated mushrooms. J. Agric. Food Chem. 2001, 49, 12343-12348. [CrossRef] [PubMed]

10. Cheung, P.C.K. Mini-review on edible mushrooms as source of dietary fiber: Preparation and health benefits. Food Sci. Hum. Wellness 2013, 2, 62-166. [CrossRef]

11. Thangthaeng, N.; Miller, M.G.; Gomes, S.M.; Shukitt-Hale, B. Daily supplementation with mushroom (Agaricus bisporus) improves balance and working memory in aged rats. Nutr. Res. 2015, 35, 1079-1084. [CrossRef]

12. Adams, L.S.; Phung, S.; Wy, X.; Ki, L.; Chen, S. White button mushroom (Agaricus Bisporus) exhibits antiproliferative and proapoptotic properties and inhibits prostate tumor growth in athymic mice. Nutr. Cancer. 2008, 60, 744-756. [CrossRef]

13. Jeong, S.C.; Koyyalamudi, S.R.; Jeong, Y.T.; Song, C.H.; Pang, G. Macrophage immunomodulating and antitumor activities of polysaccharides isolated from Agaricus bisporus white button mushrooms. J. Med. Food. 2012, 15, 58-65. [CrossRef] [PubMed]

14. Fukushima, M.; Nakano, M.; Morii, Y.; Ohashi, T.; Fujiwara, Y.; Sonoyama, K. Hepatic LDL receptor mrna in rats is increased by dietary mushroom (Agaricus bisporus) fiber and sugar beet fiber. J. Nutr. 2000, 130, 2151-2156. [CrossRef] [PubMed] 
15. Gursoy, N.; Sarikurkcu, C.; Cengiz, M.; Solak, M.H. Antioxidant activities, metal contents, total phenolics and flavonoids of seven Morchella species. Food Chem. Toxicol. 2009, 47, 2381-2388. [CrossRef] [PubMed]

16. Tsai, S.Y.; Wu, T.P.; Huang, S.J.; Mau, J.L. Nonvolatile taste components of Agaricus bisporus harvested at different stages of maturity. Food Chem. 2007, 103, 1457-1464. [CrossRef]

17. Zhou, J.; Feng, T.; Ye, R. Differentation of eight commercial mushrooms by electronic nose and gas chromatography-mass spectrometry. J. Sens. 2015, 1-14. [CrossRef]

18. Bonte, A.; Neuweger, H.; Goesmann, A.; Thonar, C.; Mäder, P.; Langenkämper, G.; Niehaus, K. Metabolite profiling on wheat grain to enable a distinction of samples from organic and conventional farming systems. J. Sci. Food Agric. 2014, 94, 2605-2612. [CrossRef]

19. Husson, O. Redox potential (Eh) and $\mathrm{pH}$ as drivers of soil/plant/microorganism systems: A transdisciplinary overview pointing to integrative opportunities for agronomy. Plant Soil 2013, 362, 389-417. [CrossRef]

20. Husson, O.; Audebert, A.; Benada, J.; Soglonou, B.; Tano, F.; Dieng, I.; Bousset, L.; Sarthou, J.P.; Joseph, S.; Menozzi, P.; et al. Leaf Eh and pH: A novel indicator of plant stress. Spatial, temporal and genotypic variability in rice (Oryza sativa L.). Agronomy 2018, 8, 209. [CrossRef]

21. Gajewski, M.; Szymczak, P.; Elkner, K.; Dabrowska, A.; Kret, A.; Danilcenko, H. Some aspects of nutritive and biological value of carrot cultivars with orange, yellow and purple-coloured roots. Veg. Crop. Res. Bull. 2007, 67, 149-161. [CrossRef]

22. Kappert, R.; Meltsch, B. Introducing a complementary investigation method concerning fruit and vegetable quality and human health. Acta Hortic. 2007, 44, 9-90. [CrossRef]

23. Bloksma, J.; Northolt, M.; Huber, M. Electro-chemical parameters. In Parameters for Apple Quality. Part 1 Report; Louis Bolk Institute: Driebergen, The Netherlands, 2001; pp. 78-81. Available online: http: //www.louisbolk.org/downloads/1279.pdf (accessed on 2 February 2018).

24. Weijn, A. Unravelling the Bruising-Discoloration of Agaricus bisporus, the Button Mushroom. Ph.D. Thesis, Wageningen University, Wageningen, The Netherlands, 2013.

25. ISO 20483:2006. Cereals and Pulses-Determination of the Nitrogen Content and Calculation of the Crude Protein Content-Kjeldhal Method; International Standard Organization: Geneva, Switzerland, 2006.

26. Horwitz, W. (Ed.) Official Methods of Analysis of AOAC International, 18th ed.; AOAC International: Gaithersburg, MD, USA, 2005.

27. Rittich, B.; Zaludova, R. Modification of the henneberg-stohmann method of fibre determination-the influence of filtration method on the content of determination fibre. Zivocisna Vyrob. 1985, 30, 289-294.

28. Melucci, D.; Bendini, A.; Tesini, F.; Barbieri, S.; Zappi, A.; Vichi, S.; Conte, L.; Toschi, T.G. Rapid direct analysis to discriminate geographic origin of extra virgin olive oils by flash gas chromatography electronic nose and chemometrics. Food Chem. 2016, 204, 263-273. [CrossRef] [PubMed]

29. Meier-Ploeger, A.; Vogtmann, H. Lebensmittelqualität-Ganzheitliche Methoden und Konzepte; Verlag, C.F. Muller: Karlsruhe, Germany, 1991; pp. 20-65.

30. Laborde, J.; Delpech, R. Dry matter content of fruitbodies of Agaricus bisporus (lange sing.): Evaluation during cropping. In Science and Cultivation of Edible Fungi; Maher, M.J., Ed.; Balkema: Rotterdam, The Netherlands, 1991; pp. 659-664.

31. Nogueira de Andrade, M.C.; Zied, D.C.; de Almeida Minhoni, M.T.; Kopytowski Filho, J. Yield of four Agaricus Bisporus strains in three compost formulations and chemical composition analyses of the mushrooms. Braz. J. Microbiol. 2008, 39, 593-598. [CrossRef]

32. Burton, K.S.; Noble, R. The influence of flush number, bruising and storage temperature on mushrooms quality. Postharvest Biol. Technol. 1993, 3, 39-47. [CrossRef]

33. Vetter, J. Chemical composition of fresh and conserved Agaricus bisporus mushroom. Eur. Food Res. Technol. 2003, 217, 10-12. [CrossRef]

34. Braaksma, A.; Schaap, D.J. Protein analysis of the common mushroom Agaricus bisporus. Postharvest Biol. Technol. 1996, 7, 119-127. [CrossRef]

35. Guillamon, E.; Garcia-Lafuente, A.; Lozano, M.; D.'Arrigo, M.; Rostagno, M.A.; Villares, A.; Martinez, J.A. Edible mushrooms: Role in the prevention of cardiovascular diseases. Fitoterapia 2010, 81, 715-723. [CrossRef]

36. Paulauskiene, A.; Danilcenko, H.; Jariene, E.; Gajewski, M.; Seroczyńska, A.; Szymczak, P.; Korzeniewska, A. Quality of pumpkin fruits in relation to electrochemical and antioxidative properties. Veg. Crop. Res. Bull. 2006, 65, 137-144. 
37. Kaciu, S.; Shala-Mayrhofer, V.; Mirecki, N.; Aliu, S.; Jezik, K. Influence of environment in electro-chemical quality of tomato. Int. J. Hortic. Sci. Technol. 2010, 16, 17-20. [CrossRef]

38. Ergun, M.; Jezik, K.M. Measuring electrochemical fruit quality of refrigerated 'hanita' plum by bioelectric vincent method. Zemdirb. Agric. 2011, 98, 15-322. Available online: https://pdfs.semanticscholar.org/d014/ 363825bb17bc6d7107324ed295f2271ef6ca.pdf (accessed on 5 October 2019).

39. Garban, Z. The fundamental problems regarding the relative hydrogen $(\mathrm{rH})$ score in biochemistry. Note, I. Theoretical bases of $\mathrm{rH}$ determination. J. Agroaliment. Process. Technol. 2008, 14, 50-57. Available online: https://www.scribd.com/document/383132708/The-fundamental-problems-regarding-the-relativehydrogen-rH-score-in-biochemistry-by-Garban-Zeno-ro (accessed on 20 October 2019).

40. Binur, K.; Serap, K. Using of electrical conductivity on food control and food process. Int. J. Agric. Environ. Res. 2016, 2, 1835-1846. Available online: https://ijaer.in/uploads/ijaer_02_130.pdf (accessed on 25 November 2019).

(C) 2020 by the authors. Licensee MDPI, Basel, Switzerland. This article is an open access article distributed under the terms and conditions of the Creative Commons Attribution (CC BY) license (http://creativecommons.org/licenses/by/4.0/). 